\title{
POTENSI PENGEMBANGAN KOMPOSIT BERPENGUAT SERAT KULIT GAHARU SEBAGAI MATERIAL PENGGANTI FIBERGLASS PADA PEMBUATAN DASHBOARD
}

\author{
Masdani $^{1}$, Yuli Dharta ${ }^{2}$ \\ 1,2 Jurusan Teknik Mesin- Politeknik Manufaktur Negeri Bangka Belitung \\ Kawasan Industri Airkantung Sungailiat-Bangka, 33211 \\ Tel: 0717-93586, Fax: 0717-93585, danhazehaz@yahoo.com
}

\begin{abstract}
The development of industrial in the utilization of composites as a substitute of metal materials that are used is fiberglass. However, fiberglass is considered not environmentally friendly because difficult to decipher. The technology advances, it is now widely used from composite materials with natural fibers. This research was conducted to obtain data about mechanical ability in the tensile strength, impact strength and physical form of Gaharu skin fibers using polyester matrix BQTN 157 with volume fraction variations made by hand lay-up method. This research is expected to be useful in automotive, manufacturing industry and household appliances are environmentally friendly. The maximum value of tensile strength is $34.574 \mathrm{MPa}$ in $45 \%$ fiber volume fraction. However, there is a decrease in the tensile strength value in the 50\% fiber volume fraction, which is $22,635 \mathrm{MPa}$, this is due to the large amount of fiber content so that the matrix spread to the fiber is uneven. The maximum impact strength value is 62.76 $\mathrm{kJ} / \mathrm{m}^{2}$ at $50 \%$ fiber volume percentage. Based on the results of testing the comparison of the fiber and matrix volume fractions greatly affect the tensile strength and impact. The results show tensile and impact tests have met the plastic standards used car dashboards.
\end{abstract}

Keywords: Natural Fiber, Composite, Gaharu skin, Tensile Test, Impact Test

\begin{abstract}
Abstrak
Perkembangan dunia industri dalam pemanfaatan komposit sebagai pengganti bahan logam yang banyak digunakan adalah fiberglass. Namun demikian, fiberglass dianggap tidak ramah lingkungan karena limbahnya sulit terurai. Seiring dengan kemajuan teknologi maka saat ini telah banyak digunakan dari bahan komposit dengan serat alam. Penelitian ini dilakukan untuk mendapatkan data tentang kemampuan mekanik berupa kekuatan tarik, kekuatan impak serta bentuk fisik dari serat kulit gaharu menggunakan matriks polyester BQTN 157 dengan variasi fraksi volume yang dibuat dengan metode hand lay-up. Penelitian ini diharapkan dapat bermanfaat dalam bidang otomotif, industri manufaktur dan peralatan rumah tangga yang ramah lingkungan. Nilai maksimum kekuatan tarik adalah 34,574 MPa terdapat pada fraksi volume serat $45 \%$. Namun ada penurunan nilai kekuatan tarik pada fraksi volume serat 50\% yaitu 22,635 MPa, ini disebabkan karena banyaknya kandungan serat sehingga penyebaran matriks terhadap serat tidak merata. Nilai kekuatan impak maksimum yaitu $62,76 \mathrm{~kJ} / \mathrm{m}^{2}$ pada persentase volume serat $50 \%$. Berdasarkan hasil pengujian perbandingan fraksi volume serat dan matriks sangat mempengaruhi kekuatan tarik dan impak. Hasil ini menunjukkan uji tarik dan uji impak sudah memenuhi standar plastik yang digunakan dashboard mobil.
\end{abstract}

Kata kunci: Serat Alam, Komposit, Kulit Kayu Gaharu, Uji Tarik, Uji Impak

\section{PENDAHULUAN}

Perkembangan teknologi bahan saat ini semakin pesat, menjadi faktor utama dalam pemenuhan kebutuhan bahan dengan karakteristik tertentu. Seiring dengan kemajuan teknologi, maka saat ini telah banyak digunakan dari bahan komposit dengan serat alam. Dua faktor paling penting yang mendorong dari penggunaan serat alam oleh industri yaitu biaya dan berat. Meskipun demikian kemudahan daur ulang komponen juga merupakan pertimbangan akhir yang semakin meningkat untuk memenuhi persyaratan dari petunjuk untuk umur komponen [1]. 
Hutan di Indonesia merupakan salah satu sumber kekayaan alam yang dapat dipertahankan bila dipelihara dan dikelola dengan baik. Indonesia adalah produsen gaharu terbesar di dunia dan menjadi tempat tumbuh endemik beberapa species gaharu komersial dari marga Aquilaria. Tanaman ini, di Indonesia dikelompokkan sebagai produk komoditi hasil hutan bukan kayu (HHBK) [2]. Budidaya gaharu sangat cocok dikembangkan dalam meningkatkan hasil hutan non kayu. Sejalan dengan perkembangan ilmu dan teknologi industri kimia serta farmasi didukung berkembangnya paradigma dunia kedokteran dan pengobatan untuk kembali memanfaatkan bahan tumbuhan alami (back to nature) produk gaharu selain dibutuhkan sebagai bahan industri parfum dan kosmetik juga banyak dibutuhkan sebagai bahan obat herbal [3].

Beberapa peneliti telah melakukan penelitian mengenai potensi pengembangan komposit berpenguat serat diantaranya penelitian komposit berpenguat serat kulit waru (Hibiscus Tiliaceus) kontinyu laminat sebagai material pengganti fiberglass pada pembuatan lambung kapal. Hasil penelitian menunjukkan terdapat pengaruh alkali $\mathrm{NaOH} 5 \%$ terhadap kekuatan tarik dan kekuatan bending. Spesimen komposit yang diperkuat serat kulit waru dengan perlakuan $\mathrm{NaOH} 5 \%$ selama 2 jam harga kekuatan tariknya hampir sama antara arah sudut serat $0^{\circ} / 0^{\circ} / 45^{\circ} /-45^{\circ} / 0^{0} / 0^{0}$ yaitu $86,14 \mathrm{~N} / \mathrm{mm}^{2}$ [4].

Penelitian Chandrabakty [5] menganalisa pengaruh perlakuan permukaan terhadap sifat kimia pada serat kulit batang melinjo yang berkaitan dengan sifat mekanis serat. Proses dilakukan dengan memberikan perlakuan permukaan pada serat kulit batang melinjo, yaitu perebusan dengan media air selama 3 jam dan media $\mathrm{NaOH}$ 5\% masing-masing selama 2 jam dan 3 jam. Hasil penelitiannya memberikan dampak pada sifat kimia, fisika dan sifat mekanis.

Penggunaan komposit dewasa ini kian meningkat disegala bidang kehidupan seperti body mobil, body pesawat terbang, peralatan olahraga dan lain-lain. Trend perkembangan komposit beralih dari komposit dengan material penyusun sintesis (fiberglass) ke komposit dengan material penyusun dari bahan alami [6].

Solusi mencari serat alam alternatif yang memiliki sifat mekanik yang tinggi dipandang penting dilakukan. Pohon gaharu merupakan salah satu jenis tanaman yang menghasilkan serat pada bagian kulit pohonnya. Sampai saat ini pemanfaatan serat kulit pohon gaharu masih terbatas pada industri dan belum diolah menjadi produk teknologi. Dahulu, serat kulit pohon gaharu dimanfaatkan oleh masyarakat sebagai bahan tali, karena harga tali plastik jauh lebih murah dan mudah didapatkan akibatnya pembuatan tali dari bahan serat kulit pohon gaharu semakin berkurang. Tuntutan teknologi ini disesuaikan juga dengan keadaan alam yang mendukung untuk pemanfaatannya secara langsung. Oleh karena itu, pemanfaatan serat kulit pohon gaharu sebagai penguat bahan komposit dibidang rekayasa merupakan salah satu gagasan yang perlu dikembangkan.

Berdasarkan tinjauan penelitian sebelumnya, maka penggunaan serat alam telah menjadi pilihan utama pada beberapa aplikasi dibidang industri, sehingga untuk mencapai tujuan tersebut maka perlu dilakukan penelitian tentang pemanfaatan serat kulit pohon gaharu sebagai bahan komposit dimana diharapkan komposit dengan serat ini dapat menjadi pilihan bahan dalam pembuatan bermacam produk sebagai pengganti logam maupun fiberglass yang dianggap lebih ramah lingkungan serta memiliki kualitas yang baik.

Penelitian ini dilakukan untuk mendapatkan data tentang kemampuan mekanik berupa kekuatan tarik, kekuatan impak serta bentuk fisik dari serat kulit kayu gaharu menggunakan matriks polyester BQTN 157 dengan variasi fraksi volume yang dibuat dengan metode hand lay-up. Maka dengan penelitian ini diharapkan dapat bermanfaat dalam bidang otomotif, industri manufaktur dan peralatan rumah tangga yang ramah lingkungan.

Tujuan penelitian untuk mendapatkan sifat mekanik dari bahan komposit seperti kekuatan tarik, kekuatan impak dan meneliti pengaruh kandungan fraksi volume serat kulit gaharu. Adapun manfaat dilakukan penelitian ini yaitu memperoleh informasi mengenai potensi serat kulit gaharu yang dapat menghasilkan suatu bahan baru yang berkualitas dan dapat menjadi acuan untuk penelitian berikutnya yang bertujuan lebih pada pengembangan.

\section{METODE PENELITIAN}

Pelaksanaan penelitian dilakukan dengan beberapa tahap yang digunakan untuk pedoman penelitian, langkah awal dimulai dari studi-studi literatur yang didapat dari jurnal ilmiah, internet, handbook, text book ,manual book. Selanjutnya data-data studi literatur dipelajari dan dijadikan referensi untuk melakukan penelitian. Uraian langkah-langkah tersebut tertuang pada diagram alir gambar 1. 


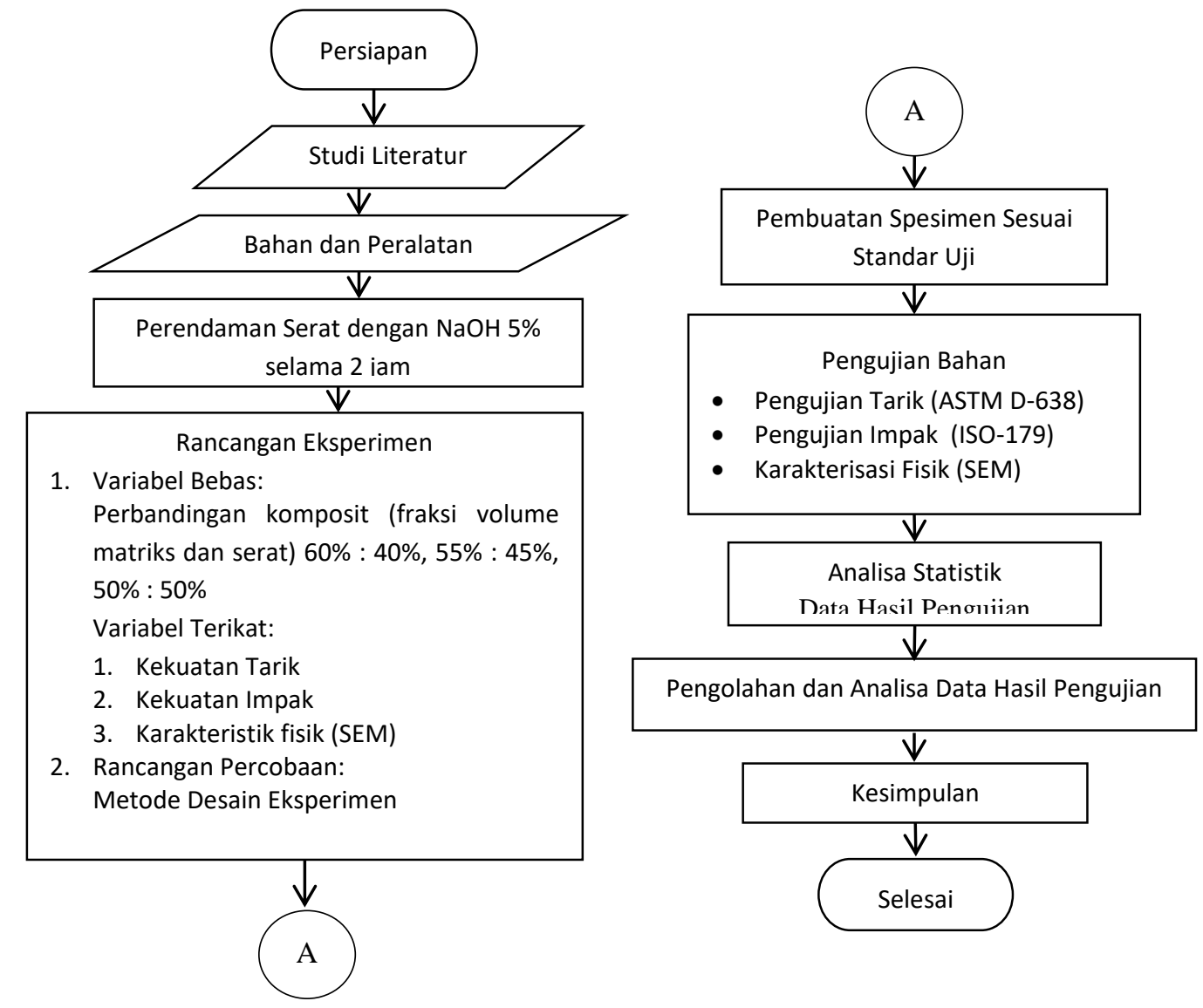

Gambar 1. Flowchart Penelitian

Setelah melakukan identifikasi masalah dan melakukan studi literatur dilakukan persiapan peralatan untuk penelitian. Peralatan yang digunakan untuk kegiatan penelitian ini adalah:

1. Serat kulit gaharu

2. Resin Unsaturated Polyester

3. Katalis

4. Wax

5. Larutan alkali $\mathrm{NaOH}$

6. Mesin uji tarik Universal Testing Machine

7. Mesin uji Impact Charpy

8. Alat Uji Scanning Electron Microscope (SEM)

\section{HASIL DAN PEMBAHASAN}

\subsection{Hasil Pengujian Tarik}

Hasil pengujian tarik didapat dengan uji tarik menggunakan mesin Universal Testing Machine dan standar pengujian yang digunakan adalah ASTM D 638 terdiri dari kekuatan tarik, modulus elastisitas dan regangan. Adapun data hasil pengujian untuk kekuatan tarik dapat dilihat pada Tabel 1. 
Tabel 1. Hasil Pengujian Kekuatan Tarik

\begin{tabular}{ccccccc}
\hline Fraksi & \multicolumn{5}{c}{ Kekuatan Tarik (MPa) } \\
\cline { 2 - 6 } $\begin{array}{c}\text { Volume } \\
\text { Matriks }+\end{array}$ & \multicolumn{5}{c}{$\begin{array}{c}\text { Replikasi } \\
\text { Rata- } \\
\text { Reta }\end{array}$} \\
\cline { 2 - 6 } Serat (\%) & 1 & 2 & 3 & 4 & 5 & \\
\hline $60: 40$ & 24,686 & 24,694 & 30,162 & 27,113 & 25,454 & 26,422 \\
$55: 45$ & 33,839 & 34,876 & 34,896 & 33,731 & 35,531 & 34,574 \\
$50: 50$ & 24,075 & 24,640 & 25,778 & 24,224 & 25,770 & 24,897 \\
\hline
\end{tabular}

Hasilnya peningkatan nilai kekuatan tarik yang kontinyu dari setiap fraksi volume serat. Nilai maksimum kekuatan tarik adalah 34,574 MPa terdapat pada fraksi volume serat $45 \%$ dan kekuatan tarik dari dashboard mobil yang memiliki jenis bahan plastik ABS high impact sebesar 20-40 MPa [7] sehingga penelitian ini sudah memenuhi standar. Penurunan nilai kekuatan tarik pada fraksi volume serat $50 \%$ yaitu 24,897 MPa, ini disebabkan karena banyaknya kandungan serat sehingga penyebaran matriks terhadap serat tidak merata. Kekuatan tarik dengan $50 \%$ volume serat menunjukkan sebaran nilai yang masingmasing replikasi cenderung turun. Sehingga dapat dikatakan persentase volume ini adalah maksimum serat yang dapat ditambahkan pada komposit.

\subsection{Hasil Pengujian Impak}

Hasil pengujian impak dengan menggunakan mesin uji Impact Charpy dan standar pengujian yang digunakan adalah ISO-179 untuk mendapatkan nilai kekuatan impak.

Tabel 2. Hasil Pengujian Kekuatan Impak

\begin{tabular}{ccccccc}
\hline \multirow{2}{*}{$\begin{array}{c}\text { Fraksi } \\
\text { Volume } \\
\text { Matriks }+\end{array}$} & \multicolumn{5}{c}{ Kekuatan Impak $\left(\mathrm{kJ} / \mathrm{m}^{2}\right)$} & \\
\cline { 2 - 6 } Serat (\%) & 1 & 2 & 3 & 4 & 5 & \\
\cline { 2 - 6 } Rata-Rata \\
$60: 40$ & 50,11 & 50,22 & 52,78 & 51,67 & 52,82 & 51,521 \\
$55: 45$ & 52,72 & 50,32 & 53,62 & 58,81 & 56,81 & 54,457 \\
$50: 50$ & 63,67 & 62,01 & 67,59 & 62,81 & 67,05 & 64,626 \\
\hline
\end{tabular}

Hasil dari pengujian impak menjelaskan terjadinya kenaikan kekuatan impak secara kontinyu dari setiap fraksi volume serat. Nilai kekuatan impak maksimum yaitu $64,626 \mathrm{~kJ} / \mathrm{m}^{2}$ pada persentase volume serat $50 \%$ dan kekuatan impak dari dashboard mobil yang memiliki jenis bahan plastik ABS high impact sebesar $13,48 \mathrm{~kJ} / \mathrm{m}^{2}$, sehingga hasil penelitian dari segi uji impak memenuhi standar dashboard mobil. Kekuatan impak meningkat dengan adanya penambahan fraksi volume serat. Peningkatan kekuatan impak ini dimungkinkan karena lebih banyak serat yang terputus dibandingkan dengan serat yang terlepas.

\subsection{Hasil Pengamatan SEM}

Analisa morfologi dan struktur mikro menggunakan SEM (Scanning Electron Microscope) dilakukan terhadap spesimen komposit setelah pengujian pada daerah patahan. Pengamatan dilakukan pada spesimen komposit yang diperkuat serat kulit gaharu dengan rasio volume matriks dan serat yaitu $60 \%$ : 40\%, 55\% : 45\%, 50\% : 50\%. Hasil photo yang didapat dari pengamatan SEM hasil pengujian tarik terlihat pada Gambar 2. Pada pengamatan photo SEM dengan rasio volume serat $40 \%$ dan $50 \%$ pada bagian patahannya, bahwa ada beberapa diantara serat terlepas (pull out) dari ikatannya. Hal ini sebabkan tidak sempurnanya ikatan antara serat terhadap matriks karena masih adanya lignin diantara serat. Juga dalam hal ini serat terlepas dikarenakan ikatan antara serat dan matriks lebih dominan pada satu sisi. 

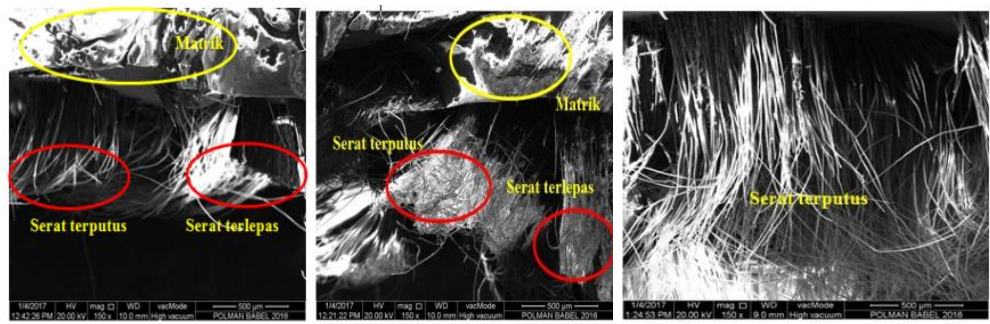

Gambar 2. Pengamatan SEM pada Uji Tarik

Pada patahan spesimen pengujian impak bahwa masih ada serat yang terlepas dari ikatannya, ini terjadi pada persentase volume serat $40 \%$ dan $45 \%$. Disebabkan karena ikatan antara serat terhadap matriks kurang menyatu. Juga dikarenakan masih adanya lignin diantara serat. Namun, dari hasil kekuatan impak yang diperoleh mengalami peningkatan secara kontinyu dari setiap masing-masing rasio volumenya. Pengamatan photo SEM rasio volume serat $50 \%$ menunjukkan adanya peningkatan ikatan yang lebih baik, terlihat dengan berkurangnya serat yang terlepas dari ikatan matriksnya. Hasil dari pengujian impak dengan rasio volume yang paling optimal yaitu pada rasio volume serat $50 \%$ dengan nilai kekuatan impak yaitu $64,626 \mathrm{~kJ} / \mathrm{m}^{2}$. Hal ini disebabkan karena semakin banyak serat dan adanya ikatan matriks dan serat yang menyatu dengan sempurna maka kekuatan impak akan semakin meningkat. Hasil pengamatan patahan spesimen komposit dapat dilihat pada Gambar 3.
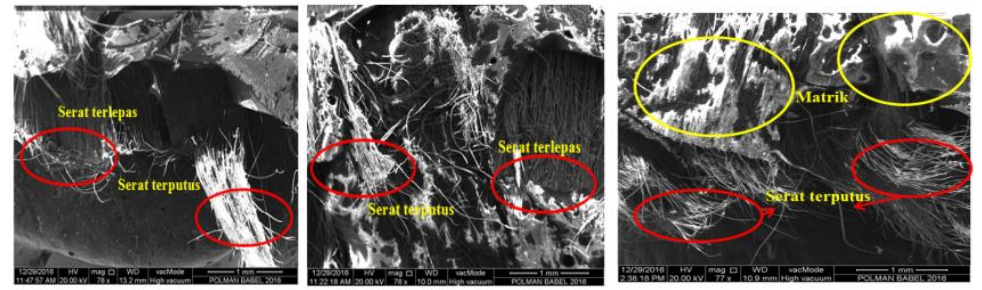

Gambar 3. Pengamatan SEM pada Uji Impak

\section{SIMPULAN}

Berdasarkan hasil penelitian yang telah dilakukan didapatkan Komposit bermatrik polyester dengan serat kulit gaharu sebagai penguat, dimana sifat mekanisnya untuk pengujian tarik mencapai beban putus dan kekuatan tarik maksimum tertinggi terjadi pada fraksi volume serat $45 \%$ dengan nilai $34,574 \mathrm{MPa}$. Pengujian impak harga kekuatan impak tertinggi terjadi pada fraksi volume serat $50 \%$ yaitu sebesar $64,626 \mathrm{~kJ} / \mathrm{m}^{2}$ dan nilai kedua uji tarik dan uji impak memenuhi standar dashboard mobil. Pada pengujian tarik penambahan jumlah persentase volume serat melebihi $45 \%$ tidak akan menaikkan kekuatan tarik komposit. Patahan serat menunjukkan semakin banyak persentase volume serat dan adanya ikatan matriks dan serat yang menyatu dengan sempurna maka kekuatan tarik semakin meningkat.

\section{DAFTAR PUSTAKA}

[1]. Brett, C.S. \& Adas, R., “Industrial Fibres: Recent and Current Developments", Proceedings of the Symposium on Natural Fibres, 2009, pp. 71-82.

[2]. Sri, W. B., Erdy, S., \& Akhmad, W, "Identifikasi Jenis-Jenis Fungsi yang Potensial Terhadap Pembentukan Gaharu dai Batang Aquilaria spp", JURNAL SILVIKULTUR TROPIKA, vol.01, pp 1-5, 2010.

[3]. Yana, "BUDIDAYA JENIS POHON PENGHASIL GAHARU", Dept. Kehutanann Badan Penelitian dan Pengembangan Kehutanan Pusat LITBANG Produktifitas Hutan Bogor, pp. 1-20, 2012.

[4]. Nurudin, A., "Potensi Pengembangan Komposit Berpenguat Serat Kulit Waru (Hibiscus Tiliaceus) Kontinyu Laminat Sebagai Material Pengganti Fiberglass Pada Pembuatan Lambung Kapal", INFO TEKNIK, vol. 12, no. 2, pp.1-9, 2011. 
[5]. Chandrabakty, S., "Fourrier Transform Infra-Red (FT-IR) Spectroscopy dan Kekuatan tarik Serat Kulit Batang Melinjo Menggunakan Modifikasi Distribusi Weibull”, Jurnal Mekanikal, vol. 5, no. 1, ISSN 2086 - 3404, pp. 434-442, 2014.

[6]. Putu, L. \& Ngakan, P.G.S., “Analisis Arah dan Perlakuan Serat Tapis Serta Rasio Epoxy Hardener Terhadap Sifat Fisis dan Mekanis Komposit Tapis/Epoxy", Jurnal Ilmiah Teknik Mesin CAKRAM, vol. 1, pp.15-21, 2007.

[7]. Application ot ABS High Impact-Acrylonitrile-Butadiene Styrene High Impact [Online], Available : http://www.omnexus.com/tc/polymerselector/polmerprofiles.aspx?id=184\&us=0\&tab=3 